\title{
PERANCANGAN FONDASI TIANG PANCANG PADA TANAH BERPOTENSI LIKUIFAKSI DI SULAWESI
}

\author{
Markus $^{1}$ dan Aksan Kawanda ${ }^{2}$ \\ ${ }^{1}$ Program Studi Sarjana Teknik Sipil, Universitas Tarumanagara, Jl. Letjen S. Parman No.1 Jakarta \\ markus.325160051@stu.untar.ac.id \\ ${ }^{2}$ Program Studi Doktor Teknik Sipil, Universitas Katolik Parahyangan, Jl. Ciumbuleuit No.94, Jawa Barat \\ aksank@dtt.untar.ac.id
}

\begin{abstract}
Indonesia is a country located in the most active earthquake paths in the world. This makes Indonesia prone to earthquakes and has the potential to experience liquefaction. Liquefaction can cause pile failure, so several things need to be considered in designing piles on potentially liquefied soils. One project in Sulawesi has a profile of uniform grained saturated soil that is susceptible to liquefaction. Two things that need to be considered in the design of piles on potentially liquefied soils is to ignore the capacity of pile friction and calculate the moment due to lateral spreading effects. Calculation of liquefaction potential is done by comparing the ratio of the cyclic stress and the cyclic resistance ratio and is compared by four other methods namely: the Seed et al. (2003), Tsuchida (1970), Seed et al. (2003), and Bray \& Sancio (2004). The lateral spreading effect is calculated by referring to the JRA Code where the liquefied soil layer gives pressure to the pile at $30 \%$ of the overburden stress and the soil layer above the liquefied soil gives passive soil pressure to the pole. The moment effect caused by lateral spreading results in the addition of dimensions or number of poles.
\end{abstract}

Keywords: liquefaction; lateral spreading; bearing capacity; JRA Code; pile foundation

\begin{abstract}
ABSTRAK
Indonesia adalah negara yang terletak di jalur gempa teraktif di dunia. Hal ini menyebabkan Indonesia rawan gempa dan memiliki potensi untuk mengalami likuifaksi. Likuifaksi dapat menyebabkan kerusakan/kegagalan struktur yang sangat merugikan, sehingga perlu diperhatikan beberapa hal dalam merancang tiang pada tanah berpotensi likuifaksi. Salah satu proyek di Sulawesi memiliki profil tanah pasir berbutir seragam dan jenuh air yang memiliki potensi likuifaksi. Dua hal yang perlu diperhitungkan dalam perancangan tiang pada tanah berpotensi likuifaksi adalah mengabaikan daya dukung friksi tiang dan memperhitungkan momen akibat efek lateral spreading. Perhitungan potensi likuifaksi dilakukan dengan membandingkan rasio tegangan siklik (CSR) dan rasio hambatan siklik (CRR) serta dibandingkan dengan empat metode lainnya yaitu: metode Seed et al. (2003), Tsuchida (1970), Seed et al. (2003), dan Bray \& Sancio (2004). Daya dukung aksial pada tiang pancang mengalami pengurangan $32 \%$ akibat lapisan tanah yang terlikuifaksi. Efek lateral spreading dihitung dengan acuan JRA Code dimana lapisan tanah terlikuifaksi memberikan tekanan ke tiang sebesar 30\% dari tegangan overburden dan lapisan tanah di atas tanah terlikuifaksi memberikan tekanan tanah pasif ke tiang. Efek momen yang diakibatkan oleh lateral spreading mengakibatkan penambahan dimensi ataupun jumlah tiang.
\end{abstract}

Kata kunci: likuifaksi; lateral spreading; daya dukung; JRA Code; fondasi tiang

\section{PENDAHULUAN}

Salah satu bencana alam yang sering terjadi di Indonesia adalah gempa. Hal ini bisa terjadi karena Indonesia terletak diantara 4 lempeng dunia, yaitu lempengdunia, yaitu lempng lempeng Eurasia, lempeng Filipina, lempeng Pasifik, dan lempeng Indo-Australia. Perbatasan antar lempeng merupakan tanda adanya pergerakan geologis yang dapat menyebabkan gempa bumi. Salah satu akibat gempa yang dapat mengakibatkan kerusakan atau kegagalan pada struktur tanah adalah likuifaksi. (Prakash,1981) 
Pada saat terjadi gempa, kerusakan struktur bisa terjadi akibat hilangnya kekuatan dan kekakuan tanah (likuifaksi). Hilang nya kekuatan dan kekakuan tanah ini bisa menyebabkan penurunan bangunan, kerusakan bendungan, pergerakan tanah (lateral spreading) dan bencana lainnya. Fenomana likuifaksi ini terjadi akibat beban gampa. Tanah yang sudah mengalami likuifaksi berubah sifatnya dari padat menjadi cair. (Das, 2011)

Tanah pasir berbutir seragam, jenuh air, dan nilai N-SPT rendah berpotensi mengalami likuifaksi (Seed and Iddris, 1982). Sulawesi merupakan salah satu tempat di Indonesia yang secara geologis berpotensi untuk mengalami likuifaksi. Oleh karena itu, harus dilakukan perbaikan tanah untuk menanggulangi potensi likuifaksi yang bisa terjadi agar tidak terjadi kegagalan pada struktur. Banyak metode perbaikan yang bisa dipilih tapi untuk tujuan penelitian ini akan digunakan tiang pancang sebagai cara untuk menanggulangi likuifaksi.

Mengetahui bahwa pada proyek di Sulawesi berpotensi mengalami likuifaksi maka harus dilakukan perancangan tiang dengan memperhitungkan faktor likuifaksi. Berdasarkan kondisi yang dijelaskan diatas, maka Tugas Akhir ini akan dilakukan perencanaan fondasi tiang dengan memperhitungkan efek likuifaksi. Dimulai dari perhitungan daya dukung, serta efek lateral dan aksial yang diakibatkan likuifaksi pada tiang.

\section{METODE PENELITIAN}

Bagian ini akan membahas metode-metode apa saja yang diperlukan dalam analisis serta rumus-rumus yang akan digunakan dalam perhitungan nanti.

\section{Data tanah}

Data tanah merupakan hal yang penting dan harus ada untuk melanjutkan penelitian. Data tanah dapat berupa beberapa hal, misalnya: SPT (Standard Penetration Test), CPT (Cone Penetretion Test), dan data lab. Pada pengerjaan Tugas Akhir ini digunakan data tanah yang didapat dari PT. Tarumanegara Bumiyasa, yang merupakan proyek di Sulawesi. Data tanah yang di dapat berupa boringlog dengan nilai N-SPT dan data lab hanya pada kedalaman tertentu saja. Dua data ini lah yang dijadikan dasar untuk melakukan perhitungan.

\section{Metode Chinese Criteria}

Metode chinese criteria menggunakan data lab (atterbeg limit) utuk mengetahui potensi likuifaksi. Syarat-syarat yang harus dipenuhi adalah jika Liquid Limit (LL) kurang dari 35\%, kadar berat tanah lempung (fines content) yang ukuran nya lebih dari $0.005 \mathrm{~mm}$ kurang dari 15\%, dan jika kadar air atau water content lebih dari 0.9 x LL. Berikut adalah kurva kerawanan likuifaksi chinese criteria Wang 1979:

\section{Metode Tsuchida}

Pada tahun 1970 Tsuchida mengeluarkan kurva untuk menentukan potensi likuifaksi berdasarkan data grainsize distribution. Metode ini melihat diameter butiran serta jenis tanah untuk menentukan potensi likuifaksi. Diamater butiran tanah dari data tanah dapat di plot kedalam kurva Tsuchida dan dilihat apakah berpotensi likuifaksi atau tidak. Berikut adalah kurva yang dikeluarkan oleh Tsuchida tahun 1970:

\section{Metode Seed et al.}

Pada tahun 2003 Seed et al (2003) merekomendasikan metode baru untuk menentukan tanah berpotensi likuifaksi. Metode ini menggunakan Plasticity Index (PI) untuk menentukan apakah tanah berpotensi likuifaksi atau tidak. Kurva yang direkomendasikan bisa dilihat pada gambar dibawah. Pada zona A tanah berpotensi besar untuk mengalami likuifaksi, keadaan dimana PI kurang dari 12\% dan LL kurang dari 37\% dan kadar air lebih dari 0,8(LL). Pada zona B tidak berpotensi likuifaksi tapi perlu dilakukan tes jika kadar air lebih besar dari 0,85(LL), keadaan ini jika PI lebih besar dari 12\% dan LL berada antara $37 \%$ dan $47 \%$.

\section{Metode Bray and Sancio}

Pada tahun 2006 Bray dan Sancio kemudian mengeluarkan kurva kerawanan likuifaksi juga dengan menggunakan batas-batas atterberg (modifikasi Bray and Sancio 2004) seperti Seed et al. (2003). Kurva yang direkomendasikan oleh Bray and Sancio bisa diliat di gambar dibawah ini. 


\section{Metode analisis perbandingan CSR dan CRR}

Pada tahun 1971 persamaan yang diformulasikan oleh Seed dan Idriss adalah seabagai berikut:

$$
\operatorname{CSR}=\frac{\tau a v}{\sigma^{\prime} v o}=0.65\left(\frac{a m a x}{g}\right)\left(\frac{\sigma_{v}}{\sigma^{\prime} v}\right) r_{d}
$$

dengan amax $=$ percepatan tanah puncak, $\mathrm{g}=$ percepatan gravitasi, $\sigma^{\prime}{ }_{\mathrm{v}}=$ tegangan vertikal efektif, $\sigma_{\mathrm{v}}=$ tegangan vertikal total, $\mathrm{r}_{\mathrm{d}}=$ koefisien tegangan reduksi (fleksibilitas tanah).

$$
C R R=\exp \left(\frac{(N 1)_{60 c s}}{14.1}+\left(\frac{(N 1)_{60 c s}}{126}\right)^{2}-\left(\frac{(N 1)_{60 c s}}{23.6}\right)^{3}+\left(\frac{(N 1)_{60 c s}}{25.4}\right)^{4}-2.8\right) \cdot K_{\sigma} \cdot M S F
$$

dengan $(\mathrm{N} 1)_{60 \mathrm{cs}}=$ nilai N-SPT terkoreksi, $\mathrm{K}_{\sigma}=$ faktor overburden, $\mathrm{MSF}=$ faktor magnitudo gempa

\section{Daya dukung ujung tiang pancang}

Daya dukung ujung tiang pada tanah lempung menurut Meyerhof dapat dirumuskan sebagai berikut:

$$
Q p=9 c_{u} A_{p}
$$

dengan $\mathrm{Qp}=$ daya dukung ujung tiang, Ap = luas penampang tiang, $c_{u}=$ kohesi tanah tidak tersaturasi.

Daya dukung ujung tiang pada tanah lempung menurut Vesic dapat dirumuskan sebagai berikut:

$$
Q_{p}=A_{q} q_{p}=A_{p} c_{u} N_{c}^{*}
$$

dengan $\mathrm{Qp}=$ daya dukung ujung tiang, $\mathrm{Ap}=$ luas penampang tiang, $c_{u}=$ kohesi tanah tidak tersaturasi, $\mathrm{N}_{\mathrm{c}}^{*}=$ nilai koefisien Vesic.

Daya dukung ujung tiang pada tanah lempung menurut Salgado dapat dirumuskan sebagai berikut:

$$
Q_{b}=A_{b} 10 S_{u}
$$

dengan $\mathrm{Qb}=$ daya dukung ujung tiang, $\mathrm{Ab}=$ luas penampang tiang, $s_{u}=$ kohesi tanah tidak tersaturasi.

\section{Daya dukung selimut tiang pancang}

daya dukung selimut pada tiang pancang dapat dirumuskan sebagai berikut:

$$
Q s=\sum A_{s} \cdot f
$$

dengan $\mathrm{Qs}=$ daya dukung selimut tiang, As = luas selimut tiang, $\mathrm{f}=$ unit tahanan selimut pada kedalaman tertentu f pada tanah pasir:

$$
f=K \cdot \sigma^{\prime} \cdot \tan \delta
$$

Dengan $\mathrm{K}=$ konstanta, $\sigma^{\prime}$ tegangan vertikal efektif tanah (dianggap konstan setelah $15 \mathrm{D}$ )

f pada tanah lempung:

$$
f=\alpha \cdot c_{u}
$$

Dengan $\alpha=C\left(\frac{\bar{\sigma}_{o}}{c_{u}}\right)^{0.45}, \bar{\sigma}_{o}^{\prime}=$ tegangan vertikal efektif rata-rata, $\mathrm{c}_{\mathrm{u}}=$ kohesi tanah. 


\section{Perhitungan lateral spreading (JRA Code)}

Metode ini memberikan panduan untuk merancang tiang dibawah pengauh likuifaksi terhadap momen yang terjadi akibat lateral spreading dengan mengasumsikan tiang bekerja sebagai beam dan lapisan tanah yang terlikuifaksi memberikan gaya sebesar $30 \%$ dari total tegangan overburden ke tiang, serta lapisan tanah tidak terlikuifaksi memberikan tekanan pasif tanah ke tiang.

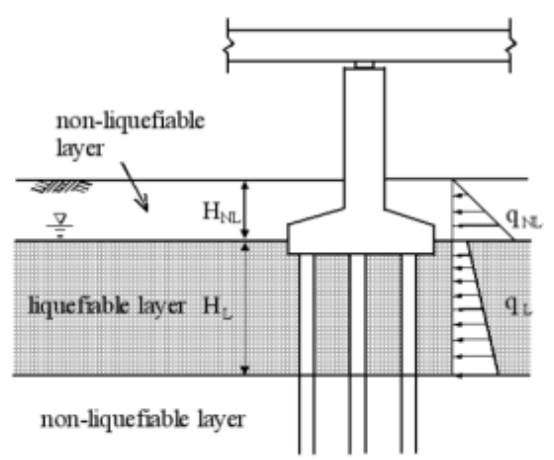

Gambar 1. Gaya horizontal menurut Japanese Road Association (Sumber: JRA,1996)

\section{Penurunan fondasi fiang}

Penurunan fondasi tiang tunggal dipengaruhi oleh tiga hal (berdasarkan rumus empiris) yaitu, penurunan akibat beban friksi; penurunan akibat ujung tiang (end bearing); penurunan akibat deformasi material tiang itu sendiri. (Rahardjo) Berikut adalah rumus yang dapat digunakan untuk menghitung penurunan tiang:

$$
S=S_{s}+S_{p}+S_{p s}
$$

dengan $\mathrm{S}=$ penurunan total fondasi tiang tunggal, $\mathrm{S}_{\mathrm{s}}=$ penurunan akibat deformasi aksial tiang tunggal, $\mathrm{S}_{\mathrm{p}}=$ Penurunan dari ujung tiang, $\mathrm{S}_{\mathrm{ps}}=$ penurunan tiang akibat beban friksi.

\section{Efisiensi kelompok tiang dan penurunan fondasi kelompok tiang}

Efisiensi kelompok tiang dapat dirumuskan seperti berikut:

- Feld: Mengurangi kapasitas daya dukung setiap tiang terdekat dengan 1/16 tanpa memperhatikan jarak tiang

- Formula Los Angeles:

$$
E=1-\frac{D}{\pi \cdot s \cdot m \cdot n}[m(n-1)+n(m-1)+(m-1)(n-1) \sqrt{2}]
$$

dengan $\mathrm{S}=$ jarak antar tiang, $\mathrm{D}=$ diameter tiang, $\mathrm{m}=$ jumlah tiang pada deretan baris, $\mathrm{n}=$ jumlah tiang pada deretan kolom.

- Formula Converse-Labbare

$$
E=1-\left[\frac{(n-1) m+(m-1) n}{90 \cdot m \cdot n}\right] \cdot \theta
$$

dengan keterangan yang sama seperti formula Los Angeles, $\theta=\arctan \left(\frac{D}{S}\right)$.

Penurunan fondasi kelompok tiang berdasarkan Vesic dapat dihitung dengan formula berikut:

$$
s_{g}=\sqrt{\frac{B_{g}}{D}} s_{e}
$$


dengan $\mathrm{S}_{\mathrm{g}}$ = penurunan kelompok tiang, $\mathrm{S}_{\mathrm{e}}=$ penurunan elastis fondasi tiang tunggal, $\mathrm{B}_{\mathrm{g}}=$ lebar dari potongan tiang kelompok, $\mathrm{D}=$ diameter tiang.

\section{LPILE}

Program ini digunakan untuk menganalisa tiang tunggal dengan beban lateral. Untuk menggunakan program ini dibutuhkan data-data fisik tanah, tiang, dan juga beban yang bekerja pada tiang, input data-data tersebut ke dalam program kemudian program akan menghitung kapasitas lateral secara komputerisasi dengan asumsi dan teori p-y curve. Hasil program atau output LPILE berupa grafik hubungan antara kedalaman dan hal-hal yang mau ditinjau seperti momen, defleksi, kekuatan geser, dan lain-lain.

\section{HASIL DAN PEMBAHASAN}

\section{Potensi likuifaksi berdasarkan data lab}

Potensi likuifaksi bedasarkan data lab digunakan data lab dari 7 bor log dengan berbagai kedalaman dapat dilihat pada Gambar 2 (metode Tsuchida), Gambar 3 (metode Seed et al), Gambar 4 (metode chinese criteria), Gambar 5 (metode Bray and Sancio).

\section{Metode Tsuchida}

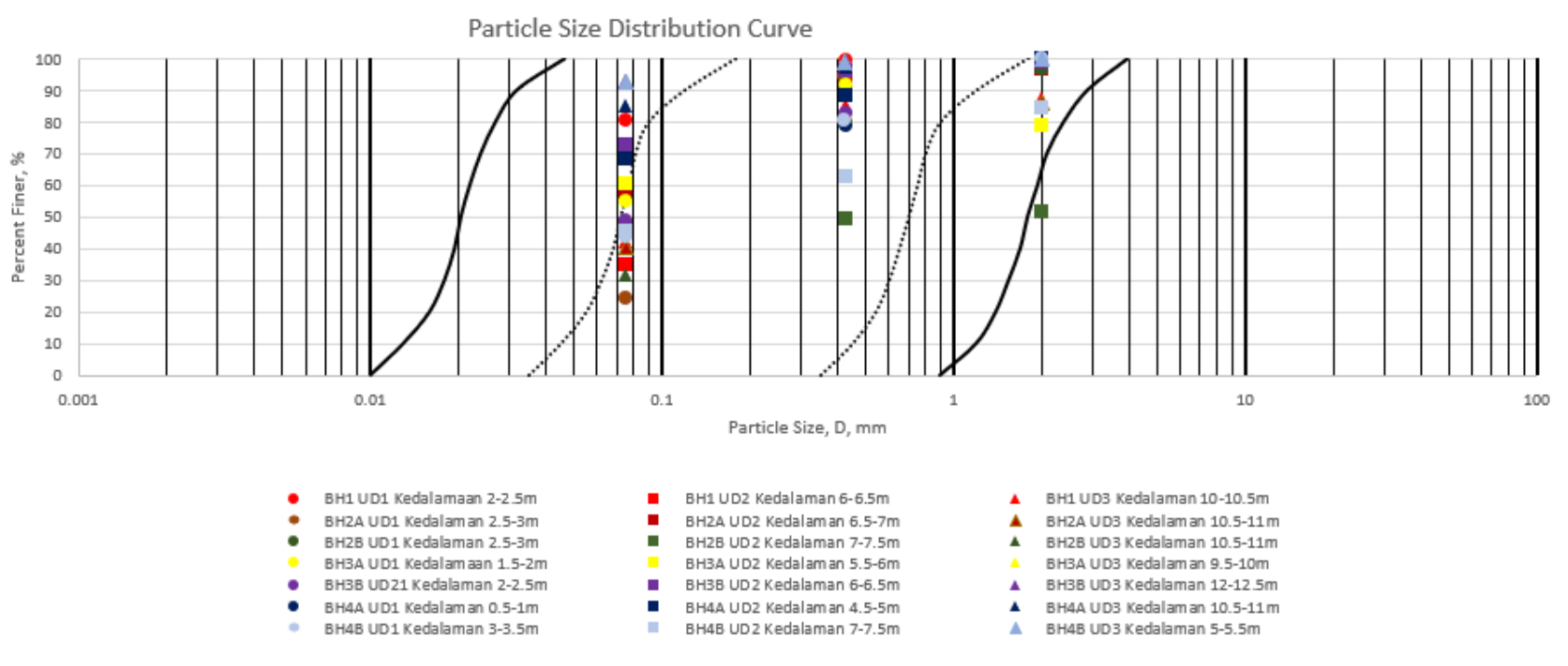

Gambar 2. Evaluasi zona likuifaksi berdasarkan kurva Tsuchida 


\section{Metode Seed et al}

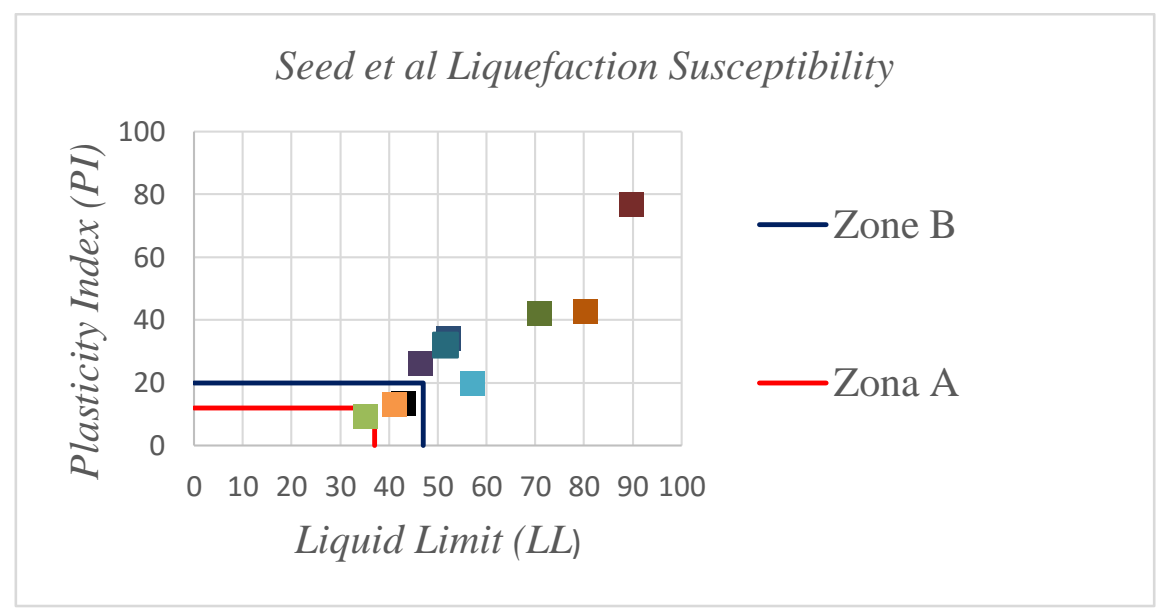

Gambar 3. Evaluasi zona likuifaksi berdasaarkan kurva Seed et al

\section{Metode Chinese Criteria}

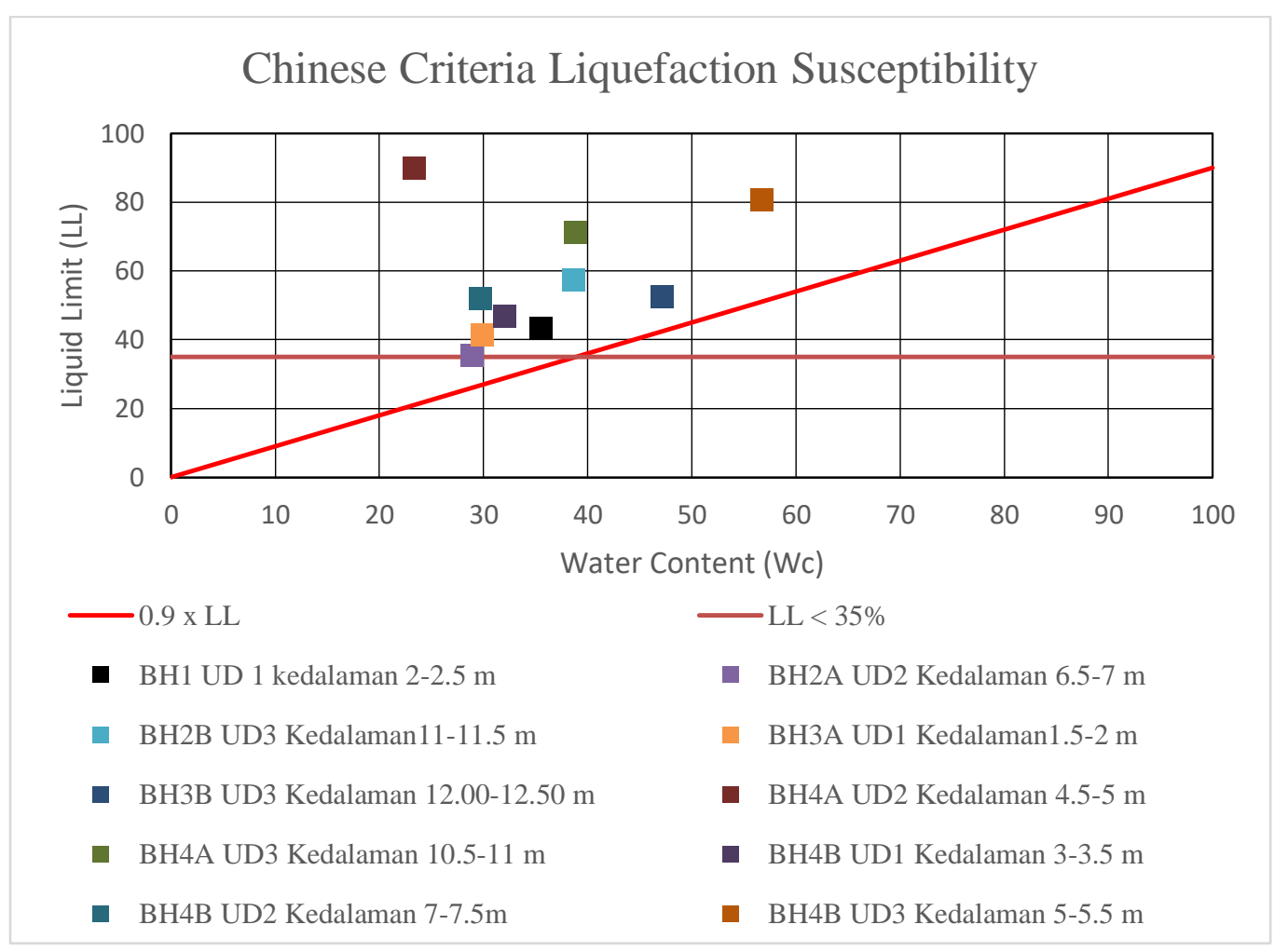

Gambar 4. Evaluasi zona likuifaksi berdasarkan kurva Chinese Criteria 


\section{Metode Bray and Sancio}

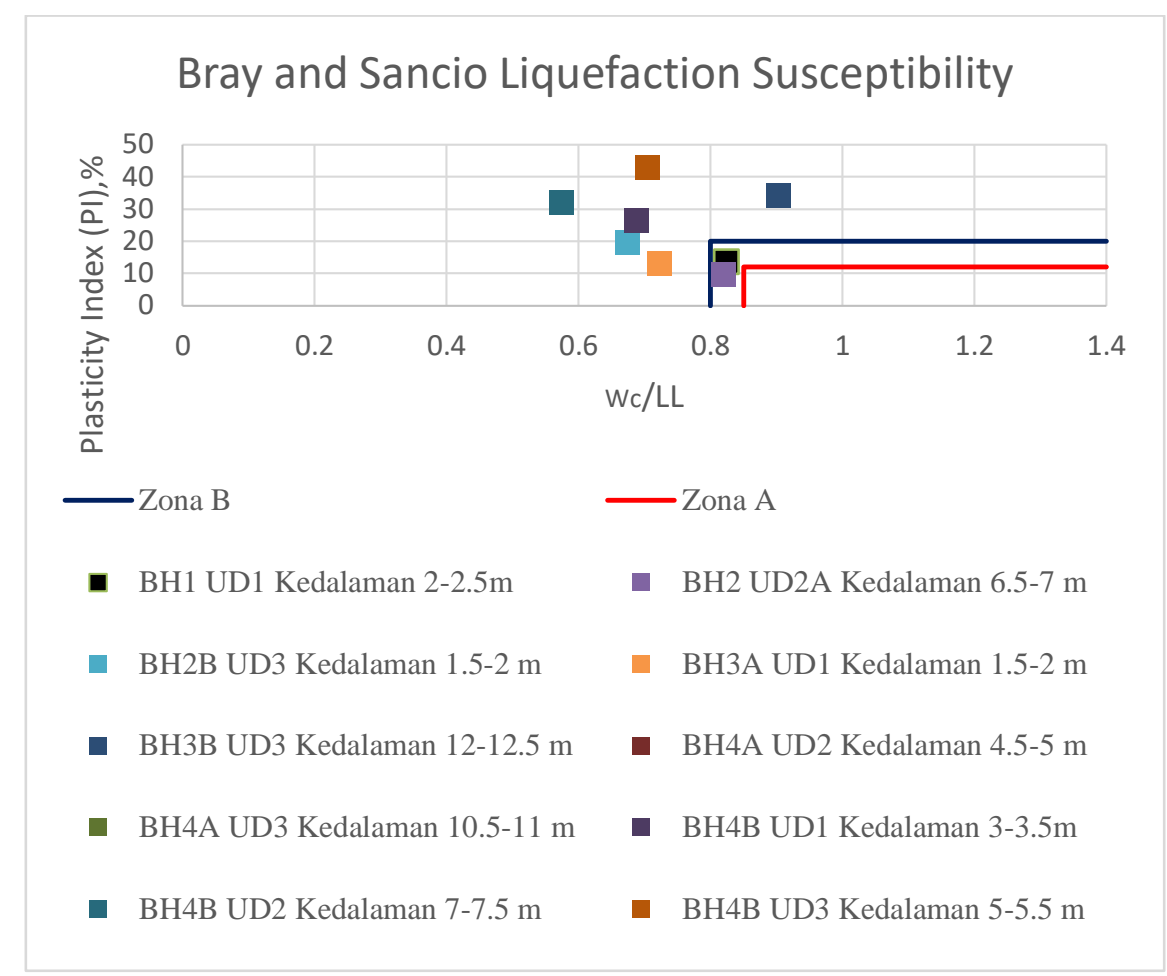

Gambar 5. Evaluasi zona likuifaksi berdasaarkan kurva Bray and Sancio

\section{Perhitungan CSR dan CRR}

Analisis CSR dan CRR menggunakan data N-SPT dari boring log yang sudah didapat, berikut adalah hasil CSR dan CRR yang sudah di dapat (Gambar 6).

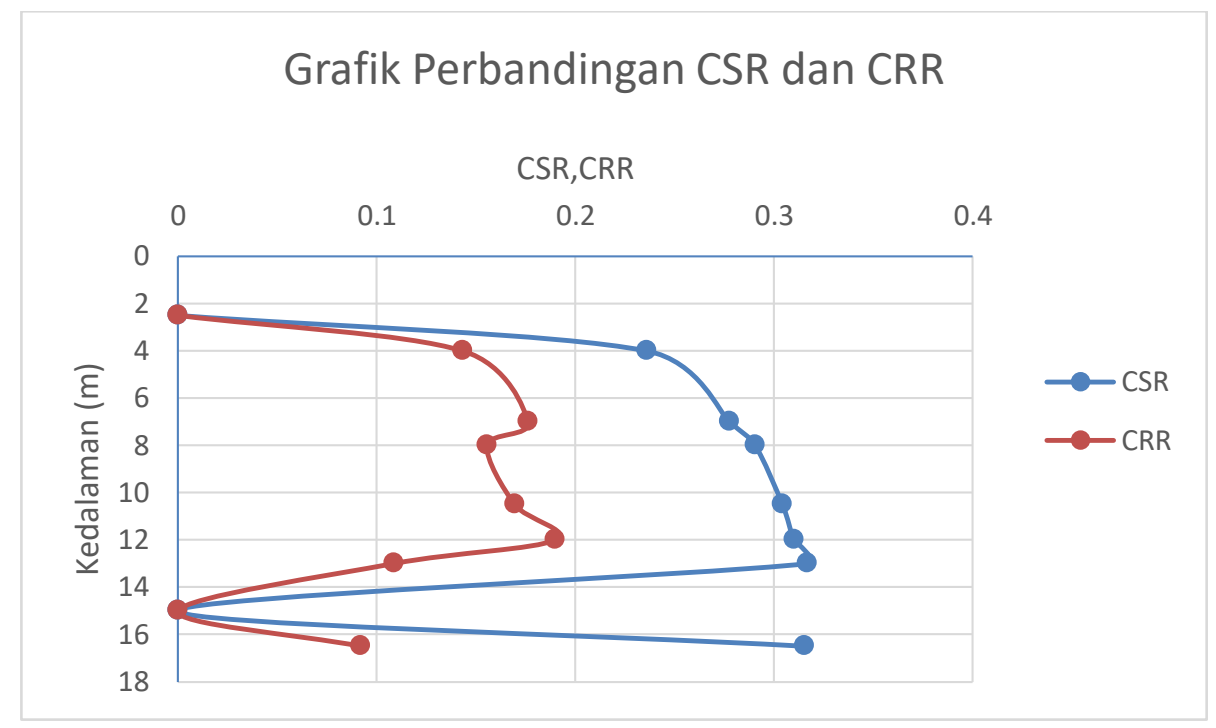

Gambar 6. Grafik perbandingan CSR dan CRR BH-1

Lapisan pasir di atas dari kedalaman 2,5 sampai dengan 13 kemudian 15 sampai 16,5 berpotensi likuifaksi karena nilai CSR < CRR (berdasarkan grafik di atas) sehingga lapisan tanah yang terlikuifaksi adalah $12 \mathrm{~m}$. 
Tabel 1. Tabel perbandingan metode likuifaksi

\begin{tabular}{ccccc}
\hline $\begin{array}{c}\text { Analisa CSR } \\
\text { dan CRR }\end{array}$ & $\begin{array}{c}\text { Metode } \\
\text { Tsuchida }\end{array}$ & $\begin{array}{c}\text { Metode Chinese } \\
\text { Criteria }\end{array}$ & $\begin{array}{c}\text { Metode Seed } \\
\text { et al. }\end{array}$ & $\begin{array}{c}\text { Metode Bray } \\
\text { and } \text { Sancio }\end{array}$ \\
\hline Berpotensi & Berpotensi & Tidak Berpotensi & Berpotensi & Berpotensi \\
\hline
\end{tabular}

\section{Analisis daya dukung tiang pancang}

Daya dukung ujung tiang berdasarkan 3 metode diambil yang terkecil hasilnya (digunakan tiang pancan PC Spun Pile, diameter 1200):

- Berdasarkan formula Meyerhof: $\mathrm{Q}_{\mathrm{p}}=9 * 130 * 0.4948=578,92 \mathrm{kN}$

- Berdasarkan formula Vesic: $\mathrm{Q}_{\mathrm{p}}=\mathrm{c}_{\mathrm{u}} \mathrm{N}_{\mathrm{c}}^{*}=0,4948 * 130 * 11.51=740,36 \mathrm{kN}$

- Berdasarkan formula Salgado: $\mathrm{Q}_{\mathrm{b}}=0,4948 * 1300=643,32 \mathrm{kN}$

Daya dukung friksi tiang dihitung dalam bentuk tabulasi dapat dilihat pada Tabel 2 untuk daya dukung selimut, Tabel 3 untuk dayadukung total tiang, Tabel 4 untuk daya dukung total tiang dengan pengaruh likuifaksi

Tabel 2. Daya dukung selimut tiang

\begin{tabular}{cccccccc}
\hline Kedalaman & N-SPT & $\mathrm{N}_{60}$ & As $\left(\mathrm{m}^{2}\right)$ & Jenis Tanah & $\begin{array}{c}\text { Total } \\
\text { Tegangan } \\
\left(\mathrm{kN} / \mathrm{m}^{2}\right.\end{array}$ & $\mathrm{f}$ & $\begin{array}{c}\text { Qs } \\
(\mathrm{kN})\end{array}$ \\
\hline 2,5 & 2 & 3,74 & 3,5 & Silty Clay & 4,66 & 0,63 & 59,55 \\
4 & 6 & $11, .22$ & 2,1 & Fine Sand & 7,27 & 18,53 & 104,84 \\
7 & 8 & 14,96 & 4,2 & Fine Sand & 12,53 & 32,11 & 363,33 \\
8 & 7 & 12,70 & 1,4 & Fine Sand & 14,31 & 31,04 & 117,05 \\
10.5 & 9 & 14,52 & 3,5 & Sand & 18,67 & 32,11 & 302,77 \\
12 & 11 & 16,74 & 2,1 & Silty Sand & 21,32 & 33,20 & 187,82 \\
13 & 5 & 7,40 & 1,4 & Fine Sand & 22,84 & 28,93 & 109,09 \\
15 & 6 & 7,96 & 2,8 & Clay & 26,64 & 0,45 & 302,72 \\
16,5 & 4 & 5,20 & 2,1 & Fine Sand & 28,77 & 27,89 & 157,76 \\
20 & 5 & 6,01 & 3,5 & Clay & 34,72 & 0,50 & 523,08 \\
22 & 5 & 5,58 & 2,8 & Clay & 38,23 & 0,52 & 312,33 \\
24 & 9 & 9,40 & 2,8 & Clay & 42,25 & 0,43 & 424,86 \\
\hline
\end{tabular}

Tabel 3. Daya dukung total tiang

\begin{tabular}{cccc}
\hline $\begin{array}{c}\text { Kedalaman } \\
(\mathrm{m})\end{array}$ & $\begin{array}{c}\mathrm{Qp} \\
(\mathrm{kN})\end{array}$ & $\begin{array}{c}\mathrm{Qs} \\
(\mathrm{kN})\end{array}$ & $\begin{array}{c}\mathrm{Qu} \\
(\mathrm{kN})\end{array}$ \\
\hline 2.5 & - & 59,55 & - \\
4 & - & 104,84 & - \\
7 & - & 363,33 & - \\
8 & - & 117,05 & - \\
10.5 & - & 302,77 & - \\
12 & - & 187,82 & - \\
13 & - & 109,09 & - \\
\hline
\end{tabular}


Lanjutan Tabel 3. Daya dukung total tiang

\begin{tabular}{cccc}
\hline 15 & - & 302,72 & - \\
16.5 & - & 157,76 & - \\
20 & - & 523,08 & - \\
22 & - & 312,33 & - \\
24 & 578,92 & 424,86 & $3,544.13$ \\
\hline
\end{tabular}

Daya dukung total tiang tanpa pengaruh likuifaksi dapat dilihat pada Tabel 3.

Daya dukung total tiang dengan pengaruh likuifaksi (mengabaikan friksi pada lapisan tanah terlikuifaksi) adalah sebagai berikut:

Tabel 4. Daya dukung total tiang dengan pengaruh likuifaksi

\begin{tabular}{cccc}
\hline $\begin{array}{c}\text { Kedalaman } \\
(\mathrm{m})\end{array}$ & $\begin{array}{c}\mathrm{Qp} \\
(\mathrm{kN})\end{array}$ & $\begin{array}{c}\mathrm{Qs} \\
(\mathrm{kN})\end{array}$ & $\begin{array}{c}\mathrm{Qu} \\
(\mathrm{kN})\end{array}$ \\
\hline 2.5 & - & 59.55 & - \\
4 & - & - & - \\
7 & - & - & - \\
8 & - & - & - \\
10.5 & - & - & - \\
12 & - & - & - \\
13 & - & - & - \\
15 & - & 302.72 & - \\
16.5 & - & - & - \\
20 & - & 523.08 & - \\
22 & - & 312.33 & $2,201.46$ \\
24 & 578.92 & 424.86 & \\
\hline
\end{tabular}

\section{Kontrol momen terhadap lateral spreading}

Bedasarkan JRA (Japanese Road Association) Code 2003 tanah yang tidak mengalami likuifaksi memberikan tekanan pasif tanah ke tiang dan tanah yang mengalami likuifaksi memberikan tekanan sebesar $30 \%$ dari tegangan overburden. Sketsa tanah dan tiang bisa dilihat pada gambar berikut

1. Mencari gaya horizontal

Pada lapisan tanah terlikuifaksi, tekanan pasif sama dengan 30\% dari total tekanan overburden sedangkan pada lapisan tanah tidak terlikuifaksi akan digunakan metode rankine seperti rumus $\sigma_{p}^{\prime}=K_{p} \gamma \mathrm{z}+2 \sqrt{K_{p}} c^{\prime}$, ditambah $\gamma_{w} * H$ untuk kedalaman dibawah muka air. Sketsadari tegangan horizontal tanah dapat dilihat pada gambar berikut: tegangan horizontal tanah untuk $2 \sqrt{K_{p}} c^{\prime}$ (Gambar 7), tegangan horizontal tanah untuk $K_{p} \gamma \mathrm{z}$ (Gambar 8), tegangan horizontal tanah akibat tekanan air pori (Gambar 9), tegangan horizontal tanah akibat lapisan tanah terlikuifaksi (Gambar 10). 


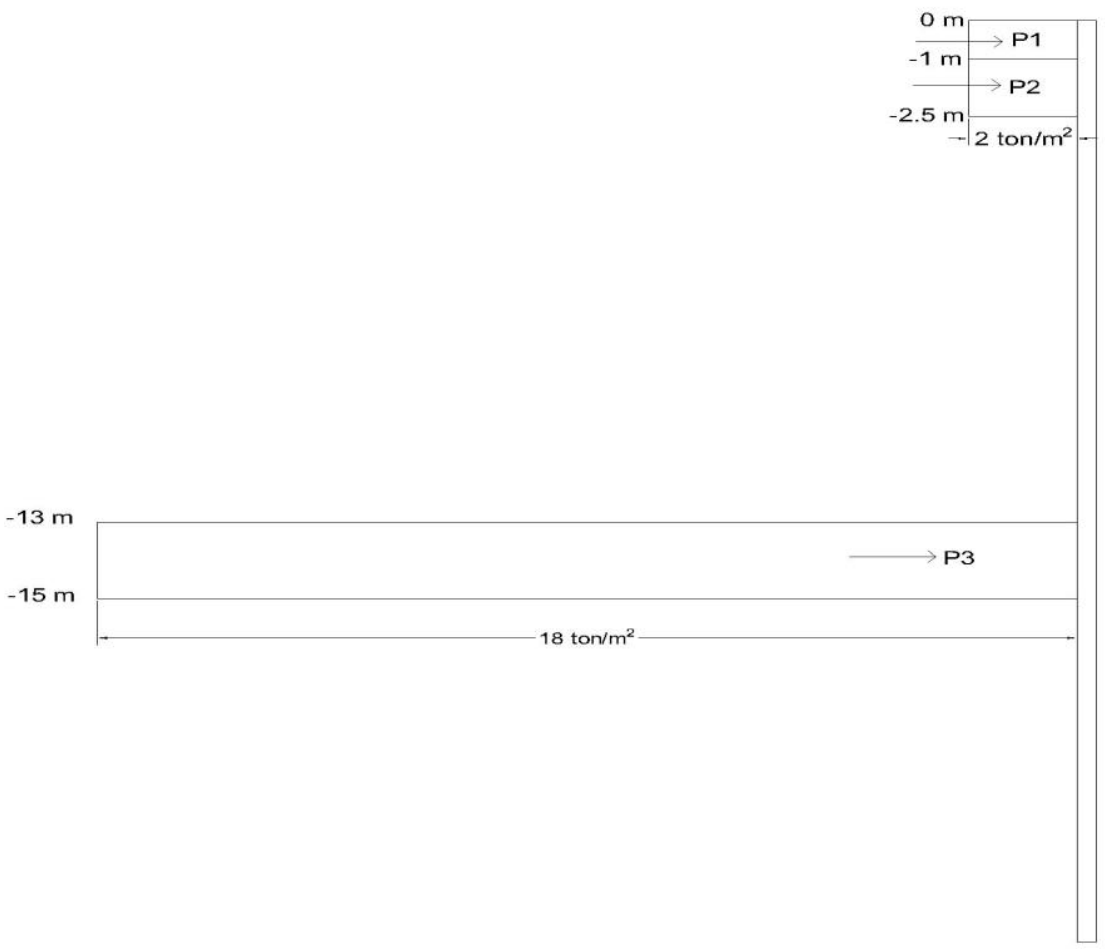

Gambar 7. Sketsa gambar tegangan horizontal lapisan Tanah $2 \sqrt{K_{p}} c^{\prime}$

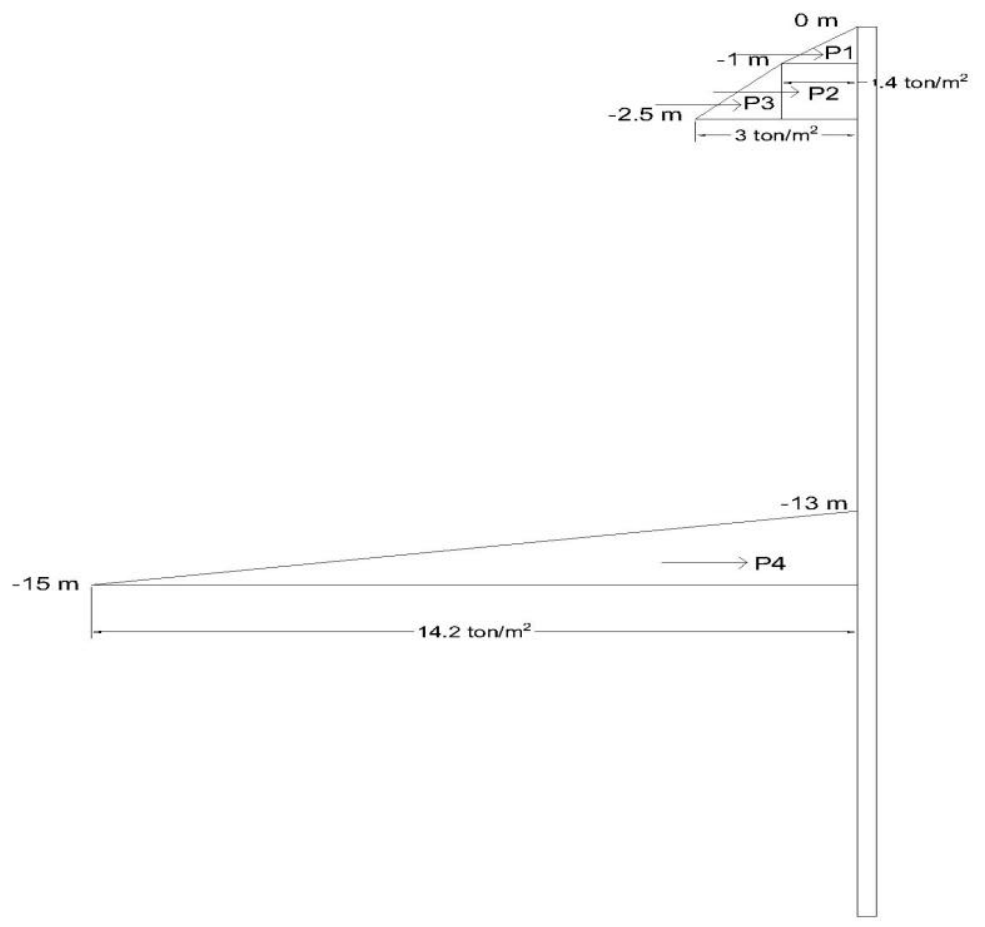

Gambar 8. Sketsa gambar tegangan horizontal akibat $K_{p} \gamma \mathrm{z}$ 


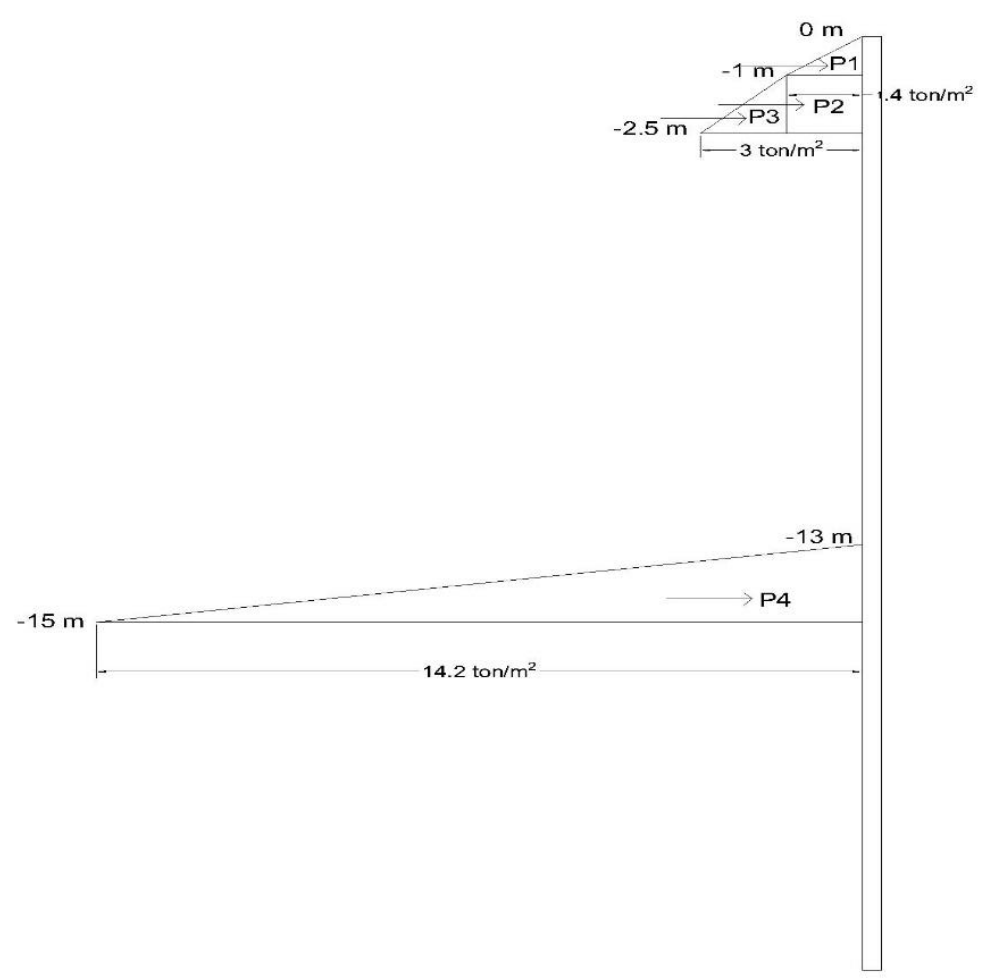

Gambar 9. Sketsa gambar tegangan horizontal akibat tekanan air pori

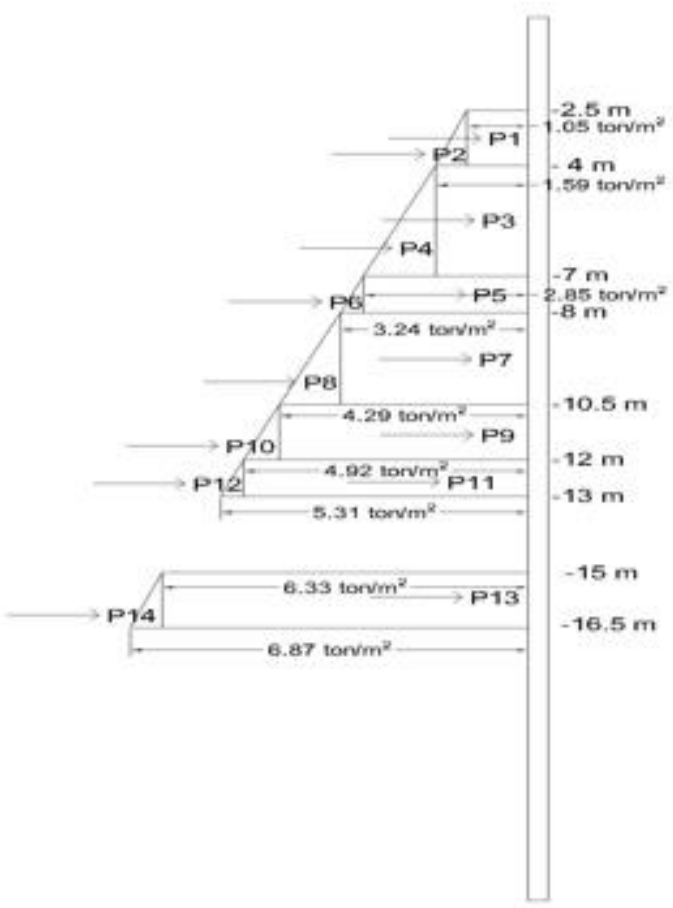

Gambar 10. Sketsa gambar tegangan horizontal lapisan tanah terlikuifaksi

Untuk menentukan gaya horizontal akibat tegangan tanah horizontal seperti sketsa di atas dapat dilakukan dengan cara menghitung luasan nya, berikut contoh perhitungan untuk P1: 
$\mathrm{P} 1=\mathrm{H} . \sigma_{p}^{\prime}=1 \mathrm{~m} * 2$ ton $/ \mathrm{m}^{2} * 1.2 \mathrm{~m}=2.4$ ton

Berikut adalah hasil perhitungan gaya horizontal dalam bentuk tabulasi: hasil perhitungan gaya horizontal akibat $2 \sqrt{K_{p}} c^{\prime}$ (Tabel 5), hasil perhitungan gaya horizontal akibat $K_{p} \gamma \mathrm{z}$ (Tabel 6), hasil perhitungan gaya horizontal akibat akibat tekanan air pori (Tabel 7), hasil perhitungan gaya horizontal akibat tanah terlikuifaksi (Tabel 8).

Tabel 5. Gaya horizontal akibat $2 \sqrt{K_{p}} c^{\prime}$

\begin{tabular}{cc}
\hline Luasan & $\begin{array}{c}\text { Gaya Horizontal } \\
\text { (ton) }\end{array}$ \\
\hline P1 & 2,4 \\
P2 & 3,6 \\
P3 & 43,2 \\
\hline Tabel 6. Gaya horizontal akibat $K_{p} \gamma \mathrm{Z}$ \\
\hline Luasan & Gaya Horizontal \\
& (ton) \\
P1 & 13,3 \\
P2 & 37,17 \\
P3 & 23,655 \\
P4 & 37,96 \\
\hline
\end{tabular}

Tabel 7. Gaya horizontal akibat tekanan air pori

\begin{tabular}{cc}
\hline Luasan & $\begin{array}{c}\text { Gaya Horizontal } \\
\text { (ton) }\end{array}$ \\
\hline P1 & 1,35 \\
P2 & 2,4 \\
\hline
\end{tabular}

Tabel 8. Gaya horizontal akibat tanah terlikuifaksi

\begin{tabular}{cc}
\hline Luasan & $\begin{array}{c}\text { Gaya Horizontal } \\
\text { (ton) }\end{array}$ \\
P1 & 1,89 \\
P2 & 0,486 \\
P3 & 5,724 \\
P4 & 2,268 \\
P5 & 3,477 \\
P6 & 0,234 \\
P7 & 9,72 \\
P8 & 1,575 \\
P9 & 7,722 \\
P10 & 5,67
\end{tabular}


Lanjutan Tabel 8. Gaya horizontal akibat tanah terlikuifaksi

\begin{tabular}{lc}
\hline P11 & 5,904 \\
P12 & 0,234 \\
P13 & 11,394 \\
P14 & 0,486 \\
\hline
\end{tabular}

Momen total akibat lateral spreading $=671,04$ Tonm sedangkang kapasitas momen crack pada tiang adalah 208 Tonm sehingga perlu ditambah jumlah tiang nya menjadi 4 tiang agar dapat menahan momen akibat lateral spreading.

\section{Penurunan fondasi tiang}

Penurunan pada fondasi tiang tunggal dapat dihitung berdasarkan rumus berikut:

$\mathrm{S}=\mathrm{S}_{\mathrm{s}}+\mathrm{S}_{\mathrm{p}}+\mathrm{S}_{\mathrm{ps}}$

$S=0.75+22.95+69.57=93,27 \mathrm{~mm}$

\section{Analisis program}

Berikut adalah analisis dengan program setelah menginput data berupa beban terdistribusi merata, data-data fisik tanah menunjukkan defleksi dan momen yang terjadi pada tiang (Gambar 11)



Gambar 11. Tampilan hasil analisis program

Karena tidak memenuhi persyaratan maka muncul warning message pada hasil output dari program ini (Gambar 12), sehingga tidak bisa dijadikan faktor tambahan dalam hasil keseluruhan penelitian saya.

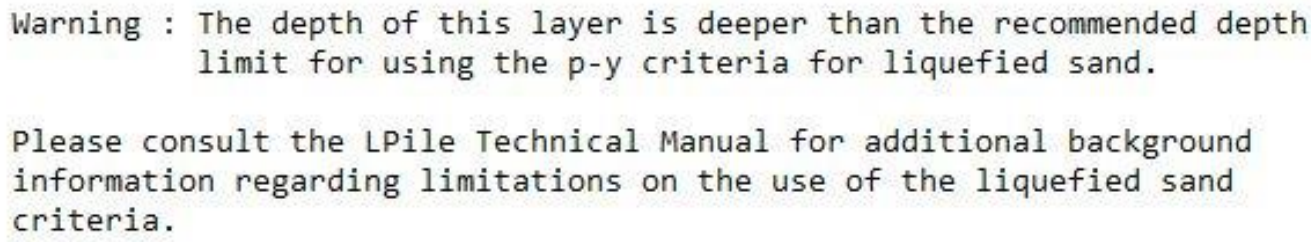

Gambar 12. Warning message pada hasil output 


\section{KESIMPULAN DAN SARAN}

\section{Kesimpulan}

Berdasarkan hasil analisis yang telah dilakukan, maka dapat disimpulkan bebeberapa hal sebagai berikut:

1. Hasil analisa potensi likuifaksi memiliki kesamaan hasil dengan metode kurva Tsuchida dan Seed et al, Bray and Sancio menyatakan berpotensi sedangkan Chinese Criteria menyatakan tidak berpotensi.

2. Berdasarkan hasil analisa rasio tegangan siklis dan ketahanan tegangan siklis diperoleh pada BH-1 tebal lapisan tanah yang berpotensi mengalami likuifaksi adalah $12 \mathrm{~m}$

3. Daya dukung aksial tiang pancang PC Spun Pile ukuran 1200 tanpa pengaruh likuifaksi adalah $3.544,13 \mathrm{kN}$ sedangkan daya dukung aksialnya dengan pengaruh likuifaksi 2.201,06 kN.

4. Momen akibat lateral spreading pada PC Spun Pile ukuran 1200 dengan metode JRA Code adalah 671,04 ton.m sedangkan kapasitas momen crack tiang adalah 208 ton.m, sehingga perlu ditambah menjadi 4 tiang untuk menahan momen tersebut. (efisiensi lateral diabaikan)

5. Daya dukung aksial 4 tiang PC Spun Pile ukuran 1200 tanpa pengaruh likuifaksi setelah dikalikan dengan faktor efisiensi adalah $11.518,423 \mathrm{kN}$ dan daya dukung aksial dengan pengaruh likuifaksi adalah 7.155,2 kN

6. Penurunan tiang tunggal yang dialami tiang adalah $93,27 \mathrm{~mm}$

\section{Saran}

Berdasarkan hasil kesimpulan di atas maka dapat disarankan beberapa hal sebagai berikut:

1. Untuk mendesain tiang terhadap likuifaksi sebaiknya menggunakan parameter yang berasal dari uji lab laboratorium daripada mengandalkan banyak korelasi terhadap typical value.

2. Perhitungan lateral spreading dengan JRA code akan lebih baik jika disertai perhitungan buckling.

3. Untuk melakukan perhitungna proyek di dekat laut atau dermaga sebaiknya dipertimbangkan tinggi muka air tanah nya serta level pemancangan tiang.

\section{DAFTAR PUSTAKA}

Das, Braja M. Principles of Foundation Engineering. Global Engineering: Christopher M. Shortt, 2011. Prakash, Shamsher. Soil Dynamics. Missouri: McGraw-Hill, 1981.

Rahardjo, P.P. Manual Pondasi TIang Edisi 3. 2005.

Sancio, J. D. Bray and R. B. "Assessment of The Liquefaction Susceptibility of Fine Grained Soil." Journal of Geotechnical Engineering (2006): 1165-1177.

Seed, H.B. and I.M. Idriss. Ground Motions and Soil Liquefaction during Earthhquakes. Calfornia, 1982.

Tsuchida, H. "Prediction and countermeasure against the liquefaction in sand deposits." Seminar in the Port and Harbor Research Institute, (1970).

Wang, W. "Some Findings in Soil Liquefaction." Report Water Conservancy and Hydro-electric (1979): 1-17.

JRA. Japanese Road Association, Specification for Highway Bridges, Part V, Seismic. 1996. 